\title{
The influence of selected senses on consumer experience: A brandy case
}

\author{
Authors: \\ Chris Pentz ${ }^{1}$ \\ Charlene Gerber ${ }^{1}$ \\ Affiliations: \\ ${ }^{1}$ Department of Business \\ Management, Stellenbosch \\ University, South Africa \\ Correspondence to: \\ Chris Pentz \\ Email: \\ cdpentz@sun.ac.za \\ Postal address: \\ Private Bag X1, Matieland, \\ 7601, South Africa \\ Dates: \\ Received: 10 Aug. 2012 \\ Accepted: 27 Mar. 2013 \\ Published: 14 May 2013 \\ How to cite this article: \\ Pentz, C. \& Gerber, C., \\ 2013, 'The influence of \\ selected senses on consumer \\ experience: A brandy case', \\ Acta Commercii 13(1), Art. \\ \#183, 7 pages. http://dx.doi. \\ org/10.4102/ac.v13i1.183

\section{Copyright:} \\ (C) 2013. The Authors. \\ Licensee: AOSIS \\ OpenJournals. This work \\ is licensed under the \\ Creative Commons \\ Attribution License.
}

Read online:
Orientation: Sensory marketing has become a popular marketing technique to enhance consumer experience. Researchers have suggested that marketers should incorporate as many senses as possible in order for sensory marketing to be effective.

Research purpose: To investigate the influence of selected senses - sight, sound and smell on consumers' experience, specifically in terms of the tastiness of brandy.

Motivation for the study: Even though the use of the senses such as sight, sound and smell is a popular sensory marketing tool in the field of experiential marketing, applying such marketing techniques is a challenging and costly exercise for marketers, and researchers have called for more studies on senses and consumer experience.

Research design, approach and method: A full factorial laboratory experiment $(2 \times 2 \times 2)$ was conducted where 240 spirits consumers indicated the tastiness of a brandy sample under certain conditions.

Main findings: Results revealed that, within a laboratory setting, consumers recorded lower levels of tastiness under conditions where more senses were manipulated than in conditions where less senses were manipulated.

Practical/managerial implications: The results of the study coincided with previous results, which indicated that, within certain product categories, sensory marketing could actually decrease the consumer's experience as sensory overload could occur.

Contribution/value-add: In the endeavour to reduce possible sensory overload in the alcohol industry, the findings suggest that marketers should not apply sensory marketing indiscriminately to all product categories. For example, on a retail level, where experimental marketing might be too costly or even too complex to apply to some product categories, marketers should rather rethink the use of sensory marketing strategies within certain industries and focus on other marketing strategies, such a brand building.

\section{Introduction}

'Advertising is not what it used to be. Despite the fact that we are using more and more marketing resources communicating with consumers, the returns are ever diminishing' (Lindstrom 2005). Consumers are bombarded with information and, as a result, modern-day marketers need to investigate new ways of breaking through the advertising clutter to reach their target consumers more effectively. In an attempt to break through this clutter, Berry, Carbone and Haeckel (2002) argued that managers should create value for customers by means of experiences. As a result, companies started to move away from traditional 'features-and-benefits' marketing toward creating experiences for their customers by means of so-called 'experiential marketing'.

Traditional marketing views consumers as rational decision makers who are interested in functional features and benefits, whereas experiential marketing views consumers as rational and emotional beings who are interested in achieving pleasurable experiences (Schmitt 1999). McCole (2004) stated that the concept of experiential marketing would rise in importance, as marketing in the twenty-first century is more challenging than ever before as a result of fragmented media and clever, articulated and 'free-thinking' consumers. Customer experience relates to a set of interactions between the customer and a product and implies the customer's involvement at different levels (i.e. rational, emotional, sensorial, physical and spiritual), where the involvement is strictly personal (Gentile, Spiller \& Noci 2007; Schmitt 1999). Schmitt (1999) investigated how companies can create different types of experiences for consumers by focusing on so-called experiential modules, namely creative cognitive experiences (thinking), physical experiences, behaviours and lifestyles (acting), social-identity experiences resulting from relating to a reference or cultural group (relating), affective experiences (feeling) and, lastly, sensory experiences (sensing). 
Many products project important nonverbal cues that must be seen, heard, tasted, felt or smelled to be appreciated properly (Holbrook \& Hirschman 1982). The sense module, also referred to as sense or sensory marketing, therefore appeals to the senses, with the objective of creating sensory experiences by means of sight, sound, touch, taste and smell. Sensory marketing can be used to differentiate companies and products, motivate consumers, add value to products and enhance customer experiences (for example, by means of aesthetics or excitement) (Schmitt 1999).

In terms of alcohol consumption, a report published by Datamonitor (2008), a leading provider of online data, indicated that alcohol consumers are increasingly looking for enhanced sensory experiences. Datamonitor's study comprised a detailed quantitative analysis of on-trade alcohol consumption covering nine core developed countries across Europe, North America and Australasia: France, Germany, Italy, the Netherlands, Spain, Sweden, the UK, the USA and Australia. This fact that consumers are increasingly seeking enhanced sensory experiences was highlighted by Bruwer, Saliba and Miller (2011), who argued that firms competing in, for example, the wine industry need to increase investigations into the sensory preferences of wine-drinking consumers. Also, in Southern Africa, little research has been conducted into the sensory experiences and/or preferences of consumers.

The present study aimed to contribute to the field of experiential marketing, specifically in terms of the alcohol industry in a developing market (South Africa) and with specific focus on the experiential module of sensory marketing. To further narrow down the research and provide information to a leading distributor of spirits in South Africa, brandy was selected as the alcoholic product, with the purpose of investigating whether certain selected senses have an influence on the perceptions of South African consumers in terms of the perceived tastiness ${ }^{1}$ of an alcoholic brand. Only the senses of smell, sound and sight were selected for purposes of this study. These senses were selected because Wright (2006) argued that they could be classified as the main human senses. The results of this study could be useful for South African marketers of brandy in the development of effective sensory marketing strategies that could be appealing to brandy consumers and result in increased sales.

The article is structured as follows: In the following section, the theoretical background to sensory marketing and the human senses will be provided, followed by the objectives and methodology of the study. The final section will deal with the statistical analysis, results and managerial implications in terms of the development of marketing strategies for brandy in South Africa.

\section{Sensory marketing}

In the field of marketing, there is much debate around the reassessment of ideas and concepts that have been tried and

1.For the purposes of this article, differentiation needs to be made between tastiness (i.e. appetising) and taste (the sense). tested through the years (Hultén, Broweus \& Van Dijk 2009). A major challenge faced by all marketers is to understand how the purchase behaviour of consumers can be influenced in favour of the products or services being offered to them (Belch and Belch 2012).

As human minds have limits on the amount of stimulation that can be handled, information is usually screened from the environment (Semenik 2002). Before data can therefore be perceived, it passes through perceptual screens that protect humans from unwanted messages. These screens act as subconscious filters and can be either physiological or psychological in nature (Arens 2006). Psychological screens assess data in terms of the consumer's needs, motives, expectations and personality, whilst physiological screens involve the five senses that are used to detect incoming data and measure the dimension and strength of physical stimuli (Arens 2006).

The argument can be made that as consumers are subjected on a daily basis to high volumes of marketing communication, unconscious triggers that appeal to the basic senses of consumers (i.e. sensory marketing) might be a more effective way than traditional marketing methods in appealing to consumers (Krishna 2012). It is also believed that even though marketers have always been aware of the significance of the human senses on consumer behaviour, the senses have for many years been neglected or ignored in marketing strategies (Hultén et al. 2009; Hultén 2011).

The concept of sensory marketing can be defined as 'marketing that engages the consumers' senses and affects their perception, judgment and behavior' (Krishna 2012:332). Krishna (2012) comes to the conclusion that sensory marketing can be applied to create subconscious triggers portraying consumer perceptions of abstract ideas of products (for example the quality or sophistication of products) and that an understanding of the sensory triggers implies an understanding of the concepts of perception and senses. Even though numerous research studies have been conducted on the senses, relatively little research has been conducted in the field of sensory marketing, and the strategic use of sensory marketing is therefore fairly limited (Suhonen \& Tengvall 2009).

\section{Perception and sensation}

Over time, many inquiring individuals (such as Einstein, Socrates and Aristotle) have tried to comprehend how people come to know and understand what is happening in the world around them (Wright 2006). The concept of consumer perception is believed to play a fundamental role in the process of how humans acquire, consume and dispose of goods and services (Arnould, Price \& Zinkhan 2004). Researchers concur that perception can be defined as 'the process by which an individual selects, organises and interprets stimuli into a meaningful and coherent picture of the world' (Schiffman \& Kanuk 2010:175). Tollington (1998) points out that perceptions are formed through information 
that is received from the environment by the consumers' five senses, namely sight, touch, smell, hearing and taste, and Lindstrom (2005) argues that the majority of a person's understanding of the world is experienced through the senses. Marketers tend to agree that perception plays a vital role in marketing programmes, where the use of pictures, images, spoken and written language, colour, noise, music, tastes as well as smells are used (Wright 2006).

As far as the concept of sensation is concerned, this can be defined as 'the immediate and direct response of the sensory organs to stimuli' (Schiffman \& Kanuk 2010:175). According to Schiffman and Kanuk (2010), a stimulus (such as a product, package, brand name or advertisement) is any unit of input to any of the senses, whilst sensory receptors (the eyes, ears, nose, mouth and skin) are the human organs that receive sensory inputs. In short, it can be argued that perception is the awareness or receipt of sensory information, whilst sensation is the response to such information.

The conclusion can therefore be made that, as sensation and perception are stages of processing the senses (Krishna 2012), marketers could attempt to apply techniques to stimulate consumers' senses so that consumer experiences could be enhanced. According to Bruwer et al. (2011), a large number of cues such as product, atmospheric and sensory cues could influence, for example, wine consumers in various ways. The research on which this article is based, focused on sensory marketing, and aimed to examine the effect that (selected) senses have on consumer experiences (specifically the tastiness of a brandy).

\section{The senses}

To examine the effect that senses might have on consumer experiences, the senses will be addressed in more detail in the following section.

\section{The sense of sight}

The sense of sight is probably the most developed and prominent human sense (Hultén et al. 2009; Krishna 2012; Wright 2006). Hultén (2011) also states that sight can be regarded as the most powerful sense for discovering changes and differences in the environment, and it is also the most common sense in detecting goods or services. Of all five human senses, the sense of sight is then also the sense that has been focused on mostly by marketing practitioners (Elder et al. 2010; Hultén et al. 2009). According to Arnould et al. (2004), most past research on vision in consumer research has examined colour or more complex visual stimuli, such as words and pictures. Results of previous studies, for example, indicated that human exposure to warm hues (red-orange-yellow) raises blood pressure, heart rate and perspiration, whereas exposure to cool hues (greenblue) has the opposite effect. In applying these findings to commercial environments, results of studies showed that yellow telephone booths increase the speed of phone calls, yellow walls and fixtures result in people moving through stores at a faster pace, and orange fixtures in fast-food restaurants stimulate hunger. Colour can therefore play an important role in the success of marketing stimuli, such as the colour used in advertising or colours used for package design (Arnould et al. 2004; Wolfe, Kluener \& Levi 2006).

\section{The sense of smell}

It is believed that the human smelling ability develops and reaches a plateau at about the age of eight and then declines as humans grow older. The sense of smell is the only sense that cannot be turned off (Suhonen \& Tengvall 2009). This sense is the most direct of all senses, and odour can affect significantly an individual's evaluation of things and other people (Aitamer \& Zhou 2011; Arnould et al. 2004). The sense of smell can also be related to pleasure and happiness and is believed to be correlated closely to emotions and memories (Hultén 2011). It should, however, be noted that, even though the sense of smell is less important for humans than for many other animals, odours have a persistent and omnipresent quality that may be difficult to escape (Arnould et al. 2004). Evidence seems to suggest that good or bad feelings generated by smells in humans are being associated with upbringing, culture, learning, emotion and psychology (Wright 2006). For scent to be used as a marketing tool to attract attention to a specific product, it is vital that the scent corresponds with the product (Suhonen \& Tengvall 2009). Teller and Dennis (2012), however, argue that the effect of ambient scent on consumer-related reactions has received relatively little attention from marketing researchers in the past.

\section{The sense of hearing}

Even though hearing is largely considered to be secondary in terms of perceptual power when compared with the sense of sight, the auditory system (ears) is capable of picking up and conveying various kinds of information to the brain (Wright 2006). Arnould et al. (2004) argue that sound patterns can create a mood of relaxation or stimulation, and point out that religions and cults have been using music for many years to induce trances or other mood states. According to Assael (1995), advertisers frequently make use of music through jingles or as background themes to create positive associations with brands, whilst Hultén (2011) points out that the sense of sound can be linked to emotions and feelings and can impact brand experiences and interpretations. Marketers are, however, advised to pretest such stimuli to ensure that positive associations with a brand will indeed be created (Assael 1995).

\section{The sense of touch}

Touch or tactile perception is a sense that is different from sight and hearing in that it is not localised to one area of the body. Humans can therefore 'feel' through the skin with any part of their bodies, be it through the hands, fingers, feet, toes, arms, legs, head, face, chest or bottom (Wright 2006). According to Arnould et al. (2004) there are various complex sensations that constitute the sense of touch, and many parts 
of the human body are much more sensitive than others. Arnould et al. (2004) also point out that numerous studies have highlighted the vital effects of touch. Studies have, for example, shown that babies that were massaged gained weight as much as $50 \%$ faster than unmassaged babies, that touch is critical in the psychological as well as the physical development of children and that sustained touching can reduce a human's heart rate and can have a calming effect on a person (Arnould et al. 2004). Assael (1995) noted that consumers also use 'feel' as a means of determining quality by, for example, using the feel of textile fabrics, clothing, carpeting or furniture to evaluate the quality of the specific product.

\section{The sense of taste}

According to Wright (2006) the average adult person has approximately 10000 taste buds that are able to detect the chemical constituents of food and beverages. Taste buds are grouped according to themes (salt, sour, sweet and bitter) at various locations inside the mouth. People use the tip of the tongue to taste sweet things, the back of the tongue to taste bitter things and the sides to taste bitter things, whilst salty things are tasted up front and along the surface (Arnould et al. 2004). Assael (1995) pointed out that taste can be an elusive perception.

\section{The use of senses in sensory marketing}

Creating customer experience seems to be one of the central objectives in retail environments (Verhoef et al. 2009). Achrol and Kotler (2012) make the point that consumers satisfy their needs by means of a complex of experiences that are filtered through their senses. Experiential marketing has therefore become a popular marketing technique used by marketers in promotions. More specifically, sensory marketing has been applied in various ways in below-the-line promotions. According to research, marketers need to incorporate all the senses in sensory marketing as senses rarely operate in isolation (Krishna 2012; Wright 2006). In the field of marketing, incorporating consumers' senses of sight, smell and sound is a popular sensory marketing tool as these senses are classified as the main senses in humans (Wright 2006). Incorporating senses such as touch and taste remains a challenge for marketers as certain products such as expensive alcohols and computer software do not necessarily lend themselves to be promoted by means of touch and taste in a retail setting. Bruwer et al. (2011), for example, argued that when wine is sold in a retail setting, the focus is mainly on tangible product cues such as the grape variety and the bottle shape and size, rather than on the wine itself, as consumers cannot necessarily touch or taste the product at the retailer.

Even though the use of the senses such as sight, sound and smell is a popular sensory marketing tool in experiential marketing, applying such marketing techniques remains challenging and costly for marketers. Consequently, there has been a call from researchers for more studies on senses and consumer experience (Krishna 2012; Orth 2005). Therefore, the aim of the study being reported here was to examine the effect of senses on consumers' experiences.

\section{Research method and design Materials and procedure}

As the senses of sight, smell and sound are regarded as the main senses, only the influence of these senses on consumers' experiences was examined. To assess the influence of sight, smell and sound on consumer experiences, a $2 \times 2 \times 2$ factorial design was applied. Respondents were assigned randomly to one of eight conditions. As the spirits industry constantly uses experiential marketing in promotions, spirits drinkers were selected for purposes of the study. A screening question was used to ensure that respondents did in fact consume brandy. The objective of the screening question was to ensure that all respondents were familiar with the product category and that experience was, at least to some extent, held constant. Following the screening question, each respondent was lead to a glass cubicle where he or she had to taste a sample of the same brandy under eight different circumstances. The cubicles were in a sensory laboratory often used to test alcohol products. The facility has 12 individual soundproof tasting booths. There are small windows in each booth from which the tasting samples are served, resulting in the experiment being free from human or facilitator interruption. The tasting glasses were filled with $40 \mathrm{~mL}$ samples of a chosen brandy, which was broken down to $20 \%$ alcohol by volume. Brandy is suitable for consumer testing at $20 \%$ alcohol by volume, blended with distilled water (Schmidt 2008).

To determine whether sight, sound and smell have an impact on consumer experience, treatment effects had to be considered carefully. Since the chosen brandy had a distinctive honey smell, the impact of smell on perceived quality was investigated by giving respondents a leaflet with an enhanced honey smell. Respondents were instructed to smell the leaflet and then to taste the brandy. Sight was controlled by removing the product colour by means of a red light in each respective tasting booth. This applies to all experiments where sight is not manipulated by the product colour. Finally, the effect of sound was investigated by playing a pouring sound in the booth whilst the respondent tasted the brandy. Table 1 summarises the experimental design followed in the study.

TABLE 1: Experimental design.

\begin{tabular}{|c|c|c|}
\hline Experiment & Experimental treatment & Test \\
\hline Group 1 & Smell manipulated (Smell honey leaflet) & $\mathrm{O}_{1}$ \\
\hline Group 2 & Sight manipulated (Colour of the brandy visible) & $\mathrm{O}_{2}$ \\
\hline Group 3 & Sound manipulated (Listen to pouring sound) & $\mathrm{O}_{3}$ \\
\hline Group 4 & $\begin{array}{l}\text { Sight and smell manipulated (Colour of brandy visible, smell } \\
\text { honey leaflet }\end{array}$ & $\mathrm{O}_{4}$ \\
\hline Group 5 & $\begin{array}{l}\text { Smell and sound manipulated (Smell honey leaflet, } \\
\text { listen to pouring sound) }\end{array}$ & $\mathrm{O}_{5}$ \\
\hline Group 6 & $\begin{array}{l}\text { Sound and sight manipulated (Listen to pouring sound, colour } \\
\text { of brandy visible) }\end{array}$ & $\mathrm{O}_{6}$ \\
\hline Group 7 & $\begin{array}{l}\text { Sight, smell and sound manipulated (Colour of the } \\
\text { brandy visible, listen to pouring sound, smell } \\
\text { honey leaflet) }\end{array}$ & $\mathrm{O}_{7}$ \\
\hline Group 8 & $\begin{array}{l}\text { No treatment (No pouring sound, colour of the brandy } \\
\text { not visible, no smelling of honey leaflet) }\end{array}$ & $\mathrm{O}_{8}$ \\
\hline
\end{tabular}

Source: Author's own construction 
For the purposes of the research on which this article is based, a laboratory experiment was conducted as researchers have a higher degree of control over variables in laboratory experiments because the environment can be monitored (Zikmund \& Babin 2010). Also, laboratory experiments tend to produce the same results if repeated with similar subjects, leading to high internal validity. Generalisation of the results obtained in a laboratory should, however, be interpreted with caution. According to Malhotra (2007), if aspects of the laboratory experiment differ from the situation for which generalisations are made, external validity will be reduced. In this article, the influence of selected senses on the tastiness of a brandy was investigated. As only sight, sound and smell were investigated one can assume that in a field environment more artifacts will be present that could influence consumers' senses. Therefore, the generalisations made from results obtained in this laboratory experiment should be viewed in the context of reduced sensory experiences.

\section{The measurements}

According to Assael (1995), the sense of taste can be an elusive perception. Results of a study by Allison and Uhl (1964) revealed that when consumers were asked to taste three unlabelled brands of beer, all three brands were rated similarly, and most respondents could also not identify their regular brand. When the labels were shown, however, respondents indicated a strong preference for their regular brand. These results suggest that taste is not an objective criterion, but that it is linked inextricably to the image of a brand in the consumer's mind (Assael 1995). Krishna (2012) also states, 'tasty may have nothing to do with the sense of taste but may be largely dependent on the other senses'. Research has shown that tastiness is based on perception and not on the taste sense. For this reason, the researchers used a measurement scale to measure the tastiness of the brandy. More specifically, the nine-point (i.e. like extremely, like very much, like moderately, like slightly, neither like or dislike, dislike slightly, dislike moderately, dislike very much, dislike extremely) hedonic scale was used. The hedonic scale is the most widely used scale for assessing the liking of food (Schutz \& Cardello 2001). For the purposes of this research, respondents were prompted to indicate which term best described the tastiness of the sample that was in front of them using the hedonic scale. Thus, for the purposes of this article, the following hypotheses were postulated:
$\mathrm{H}_{1}$ : Smell influences the tastiness of a brandy.
$\mathrm{H}_{2}$ : Sound influences the tastiness of a brandy.
$\mathrm{H}_{3}$ : Sight influences the tastiness of a brandy.
$\mathrm{H}_{4}$ : Smell and sound influence the tastiness of a brandy.
$\mathrm{H}_{5}$ : Smell and sight influence the tastiness of a brandy.
$\mathrm{H}_{6}$ : Sound and sight influence the tastiness of a brandy.
$\mathrm{H}_{7}$ : Smell, sound and sight influence the tastiness of a brandy.

\section{The sample}

As 24 respondents were required for each of the eight conditions, plus one extra cell which served as a control group, 240 randomly-selected spirit consumers participated in the study. Of these, $43 \%$ were men and $36 \%$ were women. Almost a third of the respondents were between the ages of 27 and $35(29.6 \%)$, about one third were between 35 and 50 , and one third were older than 50 . Just under half of the respondents (45\%) indicated that they were primarily brandy drinkers, and that they consumed brandy at least once a week.

\section{Empirical results Trustworthiness}

Klemz (2008) proposes that data reliability in experimental marketing can be scrutinised by repeating one experimental group and correlating the repeated group with the original group. In this study, a repeat group was selected randomly (enhanced smell) and the results obtained from the repeated group correlated with the results of the original experimental group $(p<0.05)$. The data obtained from the experiments was therefore deemed reliable and valid. Levene's test of equality of error variances revealed that the error variance of the dependent variable across the eight experimental groups was equal ( $\mathrm{F}[7]=0.640 ; p>0.05)$ and, therefore, an Anova (analysis of variance) could be conducted. Table 2 depicts the results of the main and interaction effects.

\section{Main effects}

As depicted in Table 2, the results revealed no significant main effects differences. $\mathrm{H}_{1}, \mathrm{H}_{2}$ and $\mathrm{H}_{3}$ were therefore not corroborated. From this, one can conclude that no significant differences in the tastiness of the brandy were noted with regard to smell $(\mathrm{F}[1]=0.031, p>0.05)$, sight $(\mathrm{F}[1]=0.002$, $p>0.05)$ and sound $(\mathrm{F}[1]=0.350, p>0.05)$. Therefore, sight, smell and sound in isolation did not have any effect on the tastiness of the brandy.

\section{Interaction effects}

A full factorial experimental design allows researchers to draw conclusions regarding the interaction effect of variables (Montgomery 2009). In this article, the interaction of sound and smell, sound and sight, sight and smell, as well as the combination of sound, sight and smell on the consumer experience was examined. From Table 2, one can conclude that the results revealed no two-way interaction effects. $\mathrm{H}_{4^{\prime}}$ $\mathrm{H}_{5}$ and $\mathrm{H}_{6}$ were therefore not supported. As also depicted in Table 2, however, the results revealed a significant three-way interaction effect $(\mathrm{F}[1]=4.490, p<0.05) . \mathrm{H}_{7}$ was, therefore, supported. To understand the three-way effect an LSD (least significant difference) post-hoc test was conducted (Anderson, Sweeney \& Williams 2012). The results are depicted in Figure 1.

TABLE 2: Analysis of variance results.

\begin{tabular}{lllll}
\hline Interaction effects & $d f$ & Mean square & $\boldsymbol{F}$ & Sig. \\
\hline Smell & 1 & 0.103 & 0.031 & 0.860 \\
Sound & 1 & 1.159 & 0.350 & 0.555 \\
Sight & 1 & 0.007 & 0.002 & 0.965 \\
Smell* sound & 1 & 0.080 & 0.024 & 0.877 \\
Smell* sight & 1 & 0.700 & 0.211 & 0.646 \\
Sound* sight & 1 & 1.270 & 0.383 & 0.537 \\
Smell* sound* sight & 1 & 14.884 & 4.490 & $0.035^{*}$ \\
\hline
\end{tabular}

Source: Author's own construction

*, Significant at the $95 \%$ confidence level; Dependent variable, tastiness; $d f$, disk free, Sig., significance. 


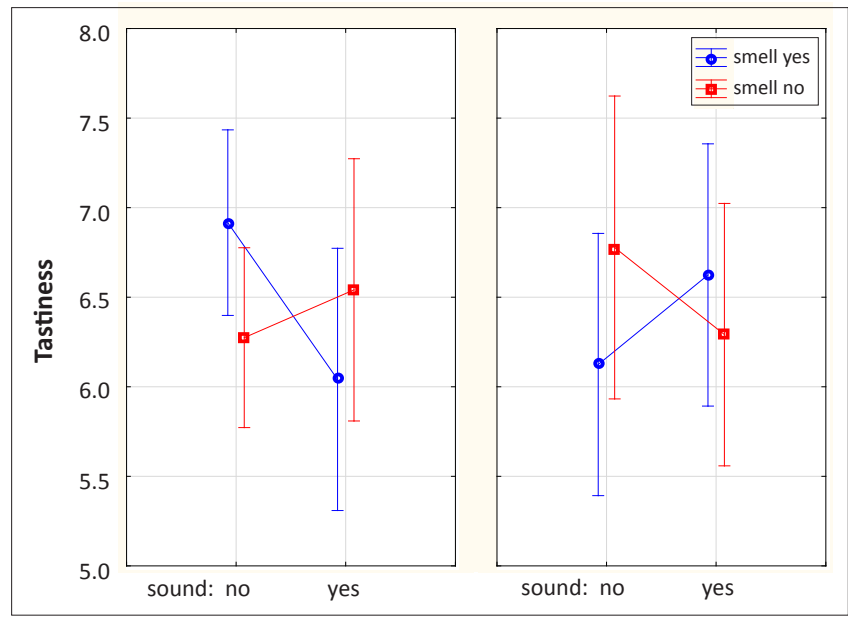

Source: Author's own construction

FIGURE 1: Three-way interaction effect of sound, sight, smell.

The results revealed that, in the case where respondents were not required to smell a honey leaflet, no pouring sounds were playing in the background, and the colour of the brandy was not visible to the respondents, the highest level of tastiness was recorded (mean $=6.917$ ). In other words, the three-way interaction between sight, sound and smell revealed that within a laboratory setting, respondents recorded higher levels of tastiness under conditions where the booth was quiet, no smelling of a leaflet was required and the colour of the brandy was not visible. In other words, in the instance where no senses cues were given, respondents recorded higher tastiness levels. It would seem that in the endeavour to incorporate all the senses, respondents could have had a sensory overload, which resulted in a reduced consumer experience.

\section{Ethical considerations}

To conduct the research in an appropriate facility, approval was granted by a leading alcohol manufacturer to use their laboratory facilities. The research on which this article is based was classified as holding low risk for potential respondents. In other words, 'the probability or magnitude of harm or discomfort anticipated in the research (was) not greater in itself than that ordinarily encountered in daily life' (Business Research 2013). Respondents were informed about the nature of the research study and anonymity was guaranteed. Informed consent was obtained by the respondents and these respondents participated voluntarily in the experiment.

\section{Discussion and conclusion}

Researchers have called for more research to investigate the connection between the senses (Krishna 2012; Puccinelli et al. 2009). Wright (2006) and Krishna (2012) concur that senses rarely operate in isolation. The results of the study being reported here coincide with these findings, as sight, sound and smell by themselves did not reveal any significant differences in the tastiness of the brandy.

The results revealed further that consumers recorded higher levels of tastiness when little disruptions were present.
Suhonon and Tengvall (2009) noted that the type of product has significant importance on the effect that the senses have on the consumer experience, specifically in the case of the alcohol industry. Therefore, with regard to the research conducted in this study, one should keep in mind that consumers might have experienced sensory overload. Krishna (2012) confirms this notion by stating that marketers could overload consumers' senses. Managers have become increasingly aware of the need to create value for their customers in the form of experiences. Applying sensory marketing seem to be an easy, effortless way of doing so. However, research revealed that marketers need to incorporate all the senses to actually enhance consumers' experiences. Incorporating all the senses is not always possible and, if it is possible, is usually costly. The results of the current study revealed that, in their endeavour to incorporate all the senses, marketers could overload consumers' senses and, as a result, actually reduce the consumer experience.

The study on which this article is based aimed to examine the influence of senses on consumer experience. Only the senses of sight, smell and sound were investigated, and tastiness, specifically, was used to measure the consumer experience. Future research could focus on incorporating all the senses. Furthermore, as this experimental study was conducted in a laboratory investigating the influence of selected senses on brandy, future research could be conducted in retail settings where consumers are exposed to more sensory experiences. Researchers could then focus on other product types, such as wine, where consumers might have less strong opinions (Suhonen \& Tengvall 2009).

Wright (2006) argued that it is important to note that the senses rarely operate in isolation. A consumer's entire understanding of the world is defined through his or her senses, which are directly linked to his or her emotions: 'the more senses you appeal to, the stronger the message'. People see and hear at the same time, or they touch and see or smell and taste or see, touch and taste (Wright 2006). Lindstrom (2005) suggested that the more positive the synergy between the senses, the stronger the connection between sender and receiver. It was also argued by Pine II and Gilmore (1998) that the more senses a certain experience engages the more effective and memorable the experience could be. The current study, however, revealed that, for specific product categories, consumers can experience sensory overloads which, and as a result, reduce consumer experience. Therefore, within the field of sensory marketing, marketers should rethink the use of sensory marketing strategies within certain industries and might rather have to focus on other marketing strategies (such as brand building) to positively influence the sales of their products.

\section{Acknowledgments}

Inspiration and some materials for this article were drawn from a Stellenbosch University Marketing Masters (2009) thesis by Ms K van Jaarsveld. The authors of the article were the supervisors for the thesis. 


\section{Competing interests}

The authors declare that they have no financial or personal relationship(s) which may have inappropriately influenced them in writing this article.

\section{Authors' contributions}

Equal contributions were made by both authors.

\section{References}

Achrol, R.S. \& Kotler, P., 2012, 'Frontiers of the marketing paradigm in the third millennium', Journal of the Academy of Marketing Science 40(1), 35-52. http:// dx.doi.org/10.1007/s11747-011-0255-4

Aitamer, G. \& Zhou, Q., 2011, 'Motives and guidance for the use of sensory marketing in retailing', unpublished Master's dissertation, Karlstad Business School, Sweden.

Allison, R.I. \& Uhl, K.P., 1964, 'Influence of beer brand identification on taste perception', Journal of Marketing Research 1(3), 36-39. http://dx.doi.org/10.2307/3150054

Anderson, D.R., Sweeney, D.J. \& Williams, T.A., 2012, Statistics for business and economics, 11th edn., South-Western Cengage Learning, Mason, $\mathrm{OH}$

Arens, W.F., 2006, Contemporary advertising, 10th edn., McGraw-Hill, New York.

Arnould, E.J., Price, L.L. \& Zinkhan, G.M., 2004, Consumers, 2nd edn., McGraw-Hill/ Irwin, New York.

Assael, H., 1995, Consumer behavior and marketing action, 5th edn., South-Western College Publishing, Ohio.

Belch, G.E. \& Belch, M.A., 2012, Advertising and Promotion. An integrated marketing communications perspective, 9th edn., McGraw-Hill, New York.

Berry, L.L., Carbone, L.P. \& Haeckel, S.H., 2002, 'Managing the total custome experience', MIT Sloan Management Review 43(3), 85-89.

Bruwer, J., Saliba, A. \& Miller, B., 2011, 'Consumer behaviour and sensory preference differences: Implications for wine product marketing', Journal of Consumer Marketing 28(1), 5-18. http://dx.doi.org/10.1108/07363761111101903

Business Research, 2013, Research methods study guide, Department of Business Management, Stellenbosch University, Stellenbosch.

Datamonitor, 2008, 'Understanding alcoholic drinking occasions: The on-trade', viewed 31 March 2009, from http://www.datamonitor.com/Products/Free/ Report/DMCM4636/020DMCM4636.htm

Elder, R.S., Aydinoglu, N.Z., Barger, V., Caldara, C., Chun, H., Lee, C.J., Mohr, G.S. \& Stamatogiannakis, A., 2010, 'A sense of things to come. Future research directions in sensory marketing', in A. Krishna (ed.), Sensory Marketing. Research on the sensuality of products, pp. 361-376, Routledge, New York.

Gentile, C., Spiller, N. \& Noci, G., 2007, 'How to sustain the customer experience: An overview of experience components that co-create value with the customer', European Management Journal 25(5), 395-410. http://dx.doi.org/10.1016/j. emj.2007.08.005

Holbrook, M.B. \& Hirschman, E.C., 1982, 'The experiential aspects of consumption Consumer fantasies, feelings, and fun', Journal of Consumer Research 9(2), 132140. http://dx.doi.org/10.1086/208906

Hultén, B., 2011, 'Sensory Marketing: The multi-sensory brand-experience concept', European Business Review 23(3), 256-273. http://dx.doi. org/10.1108/09555341111130245
Hultén, B., Broweus, N. \& Van Dijk, M., 2009, Sensory marketing, Palgrave Macmillan, Hampshire. http://dx.doi.org/10.1057/9780230237049

Klemz, B., 2008, Workshop on experimental design, Stellenbosch University, Stellenbosch, July.

Krishna, A., 2012, 'An integrative review of sensory marketing: Engaging the senses to affect perception, judgment and behavior', Journal of Consumer Psychology 22(3), 332-351. http://dx.doi.org/10.1016/j.jcps.2011.08.003

Lindstrom, M., 2005, Brand sense. Build powerful brands through touch, taste, smell, sight, and sound, Free Press, New York.

Malhotra, N.K., 2007, Marketing research: An applied orientation, 5th edn., Prentice Hall, Upper Saddle River, N.J.

McCole, P., 2004, 'Refocusing marketing to reflect practice. The changing role of marketing for business', Marketing Intelligence and Planning 22(5), 531-539. http://dx.doi.org/10.1108/02634500410551914

Montgomery, D.C., 2009, Design and analysis of experiments, John Wiley \& Sons, Danvers MA.

Orth, U.R., 2005, 'Optimum stimulation level theory and the differential impact of olfactory stimuli on consumer exploratory tendencies', Advances in Consumer Research 32, 613-619.

Pine II, B.J. \& Gilmore, J.H., 1998, 'Welcome to the experience economy', Harvard Business Review 76(4), 97-105.

Puccinelli, N.M., Goodstein, R.C., Grewal, D., Price, R., Raghubir, P. \& Stewart, D., 2009, 'Customer experience management in retailing: Understanding the buying process', Journal of Retailing 85(1), 15-30. http://dx.doi.org/10.1016/j. jretai.2008.11.003

Schiffman, L.G. \& Kanuk, L.L., 2010, Consumer behaviour, 10th edn., Pearson Education, Inc., New Jersey.

Schmidt, D., 2008, Personal interview with the sensory research analyst to the product development department of an alcohol manufacturer, Stellenbosch, May. (Notes in possession of researcher) http://dx.doi.org/10.1362/026725799784870496

Schmitt, B., 1999, 'Experiential marketing', Journal of Marketing Management 15(13), 53-67.

Schutz, H.G. \& Cardello, A.V., 2001, 'A labeled affective magnitude (lam) scale for assessing food liking/disliking', Journal of Sensory Studies 16(2), 117-159. http:// dx.doi.org/10.1111/j.1745-459X.2001.tb00293.x

Semenik, R.J., 2002, Promotion \& Integrated Marketing Communications, SouthWestern, Ohio.

Suhonen, T. \& Tengvall, J., 2009, 'Branding in the air: A study about the impact of sensory marketing', unpublished Bachelor's thesis, Department of Business Administration, Jönköping International Business School, Sweden.

Teller, C. \& Dennis, C., 2012, 'The effect of ambient scent on consumers' perception, emotions, and behaviour: A critical review', Journal of Marketing Management 28(1-2), 14-36. http://dx.doi.org/10.1080/0267257X.2011.560719

Tollington, T., 1998, 'Brands: The asset definition and recognition test', Journal of Product and Brand Management 7(3), 180-192. http://dx.doi. org/10.1108/10610429810222822

Verhoef, P.C., Lemon, K.N, Parasuraman, A., Roggeveen, A., Tsiros, M. \& Schlesinger L.A., 2009, 'Customer experience creation: Determinants, dynamics and
management strategies', Journal of Retailing 85(1), 31-41. http://dx.doi. management strategies', Journal
org/10.1016/j.jretai.2008.11.001

Wolfe, J.M., Kluener, K.R. \& Levi, D.M., 2006, Sensation and perception, Sinauer Associates, Sunderland.

Wright, R., 2006, Consumer behaviour, Thomson Publishing, London.

Zikmund, W.G. \& Babin, B.J., 2010, Exploring marking research, 10th edn., Thomson South-Western Publishing, New York. 